\title{
Opphopning av ikke-smittsom sykdom
}

\author{
Situasjoner der man observerer flere alvorlige sykdomstilfeller enn forventet innenfor et begrenset område \\ vil skape bekymring. Det finnes flere metoder for å undersøke muligheten for at slike opphopninger ikke er \\ tilfeldige. Gode forklaringer på hvorfor sykdomstilfellene har hopet seg opp, får man bare ved å inkludere \\ mulige eksponeringsvariabler i pasient-kontroll-studier. Slike studier er kostnadskrevende og tidkrevende \\ og må være godt underbygd.
}

\section{Geir Aamodt}

geir.aamodt@fhi.no

Avdeling for folkesykdommer

Divisjon for epidemiologi

Nasjonalt folkehelseinstitutt

Undersøkelser av opphopninger av smittsomme sykdommer er vesentlig for å identifisere de mikroorganismene som er årsak til sykdommene. Rask oppsporing av smittekilde og effektive tiltak for å avgrense denne reduserer risikoen for ytterligere spredning. I Norge regulerer smittevernloven denne virksomheten. Loven sikrer at helsemyndighetene får tilgang til de helseopplysningene de er avhengige av slik at de raskt kan iverksette nødvendige tiltak.

For ikke-smittsomme sykdommer er det sjelden at det er et agens som er årsaken. Utvikling av ikke-smittsomme sykdommer er et resultat av et komplekst samspill mellom biologiske mekanismer, personlig atferd, miljøfaktorer og genetiske faktorer. Ofte er patogenesen godt forstått, men faktorene som fører til sykdom bare delvis kjent.

Man skiller mellom tre grupper av motiver for å undersøke opphopning av sykdom:

- Påstander basert på bekymringsmeldinger fra lokale helsemyndigheter, publikum eller medier, ofte knyttet til en antakelse om en ytre miljøfaktor

- Innen analytisk epidemiologisk forskning - her vil kunnskap om sykdommens geografiske variasjon være hypotesegenererende for å finne ukjente miljøfaktorer

- Systematiske overvåkinger basert på nasjonale helseregistre

Et eksempel på den første gruppen er forekomsten av leukemi hos barn bosatt i nærheten av atomrenseanlegg i Storbritannia. Her ble det påvist økt forekomst av leukemi, men man fant ikke tilsvarende bevis for at stråling fra atomrenseanleggene var assosiert med forekomsten av sykdom (med unntak av bl.a. Sellafield) (1). Fortsatt er årsakene til denne kreftformen lite forstått (2).
Et eksempel på den andre gruppen er geografisk variasjon av den autoimmune tilstanden Crohns sykdom, en livslang og ofte invalidiserende lidelse som rammer personer i ung voksen alder, men der få risikofaktorer er kjent. Studier i Norge og $i$ andre land har vist at det er en geografisk opphopning av sykdomstilfeller. Dette har generert nye hypoteser for nye miljøfaktorer. Nå er interessen knyttet til hvordan mikroorganismer koloniseres i tarmen (biodiversitet) (3) og til innholdet i drikkevannet (4).

\section{«Metodene vil generere falskt positive klynger, og sanne klynger vil ikke nødvendigvis bli fanget opp»}

I etterkant av talidomidtragedien i 1960årene ble det etablert medisinske fødselsregistre i flere land, slik at man raskt kan varsle om utbrudd av tilsvarende hendelser. Et eksempel på systematisk overvåking er Bjerkedal \& Bakketeigs forskningsrapport om misdannelser blant nyfødte i Norge basert på Medisinsk fødselsregister (5).

Hvilke typer data har man for slike problemstillinger, hvilke statistiske metoder brukes for å oppdage opphopninger av sykdomstilfeller, og hva kjennetegner disse metodene?

\section{Data og definisjoner}

Man skiller mellom punktdata og områdedata, avhengig av om sykdomstilfellene er registrert som adressepunkter eller som antall forekomster innenfor et geografisk område (kommune, grunnkrets). Hvis man velger studier av adressepunkter, bør det være en tanke om eksponering bak dette valget - utfall knyttet til drikkevann vil være relatert til bosted, utfall knyttet til eksponering fra kjemiske eller andre spesifikke komponenter er knyttet til arbeidssted/skole.

Det finnes flere definisjoner av klynger/ opphopninger av sykdom. En av de meste anvendte er Andrew Lawsons «et areal innen studieområdet med en betydelig økning i risiko for sykdom» (6). Man kan også utvide definisjonen til å favne opphopning av sykdommer innenfor et begrenset område og et begrenset tidsvindu. Jeg nevner kort at de problemstillingene som gjelder for geografiske klynger, også gjelder for rom-og-tid-klynger. Man skiller også mellom opphopning (clustering) og klynge (cluster), der man med opphopning mener en betydelig økning av sykdom innen studieområdet uten å referere dette til et bestemt delområde, mens en klynge er knyttet til et avgrenset område.

\section{Statistiske metoder}

Det er utviklet mange statistiske metoder for å teste hypoteser om opphopning av sykdom og metoder for å finne/avgrense områder med økt risiko. For punktdata vil en naturlig nullhypotese være at pasienter og kontrollpersoner følger samme bosetningsmønster. For å teste en slik hypotese har Cuzick \& Edwards undersøkt hvor mange av de $k$ nærmeste naboene til hver pasient som også er pasient (7).

For å finne eventuelle opphopninger eller klynger for områdedata kan man for hvert delområde beregne forventet antall syke, under forutsetning at insidensraten er konstant, og sammenlikne disse verdiene med antallet observert syke. En slik størrelse kalles for en standardisert morbiditetsratio (SMR) og kan vises på et kart. Man benytter ofte glatting for å redusere småskalavariasjonen. For å undersøke om noen områder viser høyere eller lavere verdier enn det man kan forvente, kan man benytte konfidensintervallene til SMR-verdiene. Det er også utviklet mer presise metoder for 


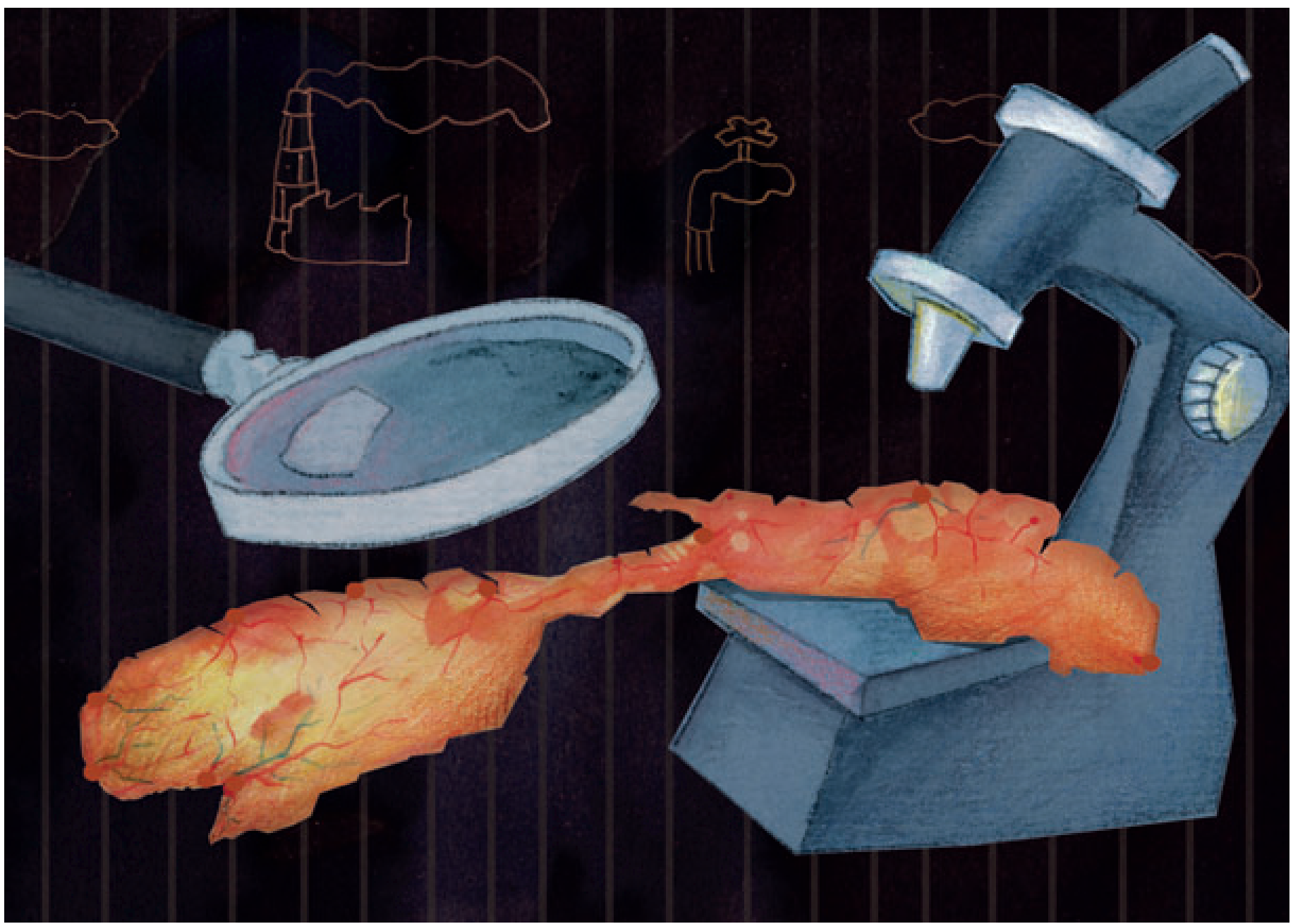

Illustrasjon Stein Løken

å identifisere delområder med signifikant høyere forekomst av sykdomstilfeller. Disse metodene er basert på sammenlikning av antall observerte med antall forventede sykdomstilfeller, men det matematiske fundamentet er ofte komplisert.

\section{Vurdering av metodene}

Muligheten til å oppdage områder med $ø$ kt risiko for sykdom varierer med hvilken statistisk metode som velges og er avhengig av klyngens form og størrelse samt forskjeller i rateratio mellom normalrisikoog høyrisikoområdene.

I 2006 undersøkte jeg, i samarbeid med to medarbeidere, hvor godt ulike statistiske metoder fanger opp klynger. Vi produserte seks klynger med ulike geometrier og størrelser basert på norske forhold (8). Disse klyngene skulle gjenspeile forskjellige scenarioer, som nedfall etter en hendelse tilsvarende Tsjernobyl-ulykken, forurensning langs et vassdrag eller forurensning langs Sørlandskysten. Vi varierte styrken i rateratio mellom høyrisikoområdet og normalrisikoområdet. Vi inkluderte tre forskjellige statistiske metoder i dette arbeidet.

Våre undersøkelser viste at klynger med avlange geometrier - elver og langs kysten - er vanskelig å fange opp, mens mer sirkulære klynger som er midt i landet, er lettere å oppdage. For relativt lave forskjeller i rateratio $(<2,5)$ er muligheten for å oppdage en klynge under $50 \%$ - det er altså stor risiko for å overse en. Det er tilsvarende vanskeligheter med falskt positive klynger. Når man utfører mange tester for å undersøke opphopninger, vil man med nødvendighet registrere klynger som det ikke vil være hold i og som skyldes den variasjonen man kan forvente mellom områder.

En annen problemstilling er knyttet til den vitenskapelige forankring for påstander om klynger. En a priori-hypotese om eksponering og risiko for sykdom er mer robust enn en post hoc-undersøkelse av en påstått klynge. I det første tilfellet kan man formulere en nullhypotese og teste om den kan forkastes eller ikke basert på data (9), i det andre tilfellet finner man først en opphopning og deretter vil man lete etter en eksponering assosiert med opphopningen. En signifikant forskjell på observerte og forventede syke innen et område trenger ikke være relatert til eksponering. Jakten på en mulig «årsak» kan være som å lete etter nålen i en høystakk med mange kandidater.

\section{Analysevansker}

Jeg har vist at de statistiske metodene «lekker i begge ender»: Metodene vil generere falskt positive klynger, og sanne klynger vil ikke nødvendigvis bli fanget opp. Det er heller ikke noen kunnskap om eksponering i en analyse av opphopninger/ klynger, og man får derfor ingen viten om eventuelle kausale effekter. Det er derfor viktig - for å unngå unødig frustrasjon å tenke gjennom på hvilket grunnlag man skal drive systematisk overvåking og initiere undersøkelser basert på bekymringsmeldinger.

I flere land finnes det dedikerte grupper som i løpet av kort tid (noen arbeidsdager) skal kunne gi et foreløpig svar på om det er styrke i en mistanke om opphopning av sykdom og avgjøre om pasient-kontroll-studier skal initieres. Dette gjelder bl.a. Rapid Inquiry Facility (RIF) i Storbritannia og EUROHEIS i andre EU-land (9). Disse enhetene skal raskt kunne:

- Kvalitetssikre diagnoser, fjerne duplikater

- Bestemme studieområde 
- Finne sammenliknbare tall for befolkningen for øvrig

- Utføre analyser for å beregne risikoen for sykdom innen spesielle områder i forhold til normalrisikoområder

- Ta stilling til resultater fra statistiske tester om det er en opphopning eller ikke

- Formidle kunnskap og resultater til befolkningen

I Norge har vi ikke noen slik enhet. Det er heller ikke hjemmel i norsk lov, tilsvarende smittevernloven, som regulerer tilgang til helseopplysninger eller adresser, for å undersøke slike påstander. I dag må undersøkelse av bekymringsmeldinger registreres som forskningsprosjekt og først godkjennes av en regional etisk komité før helseregistre kan kobles og analysene utføres. En slik ekstra runde er en viktig kvalitetssikring, men forsinker prosessen.

Det har vært uenighet i epidemiologimiljøet om analyser av opphopninger og på hvilket grunnlag man skal gå videre for å undersøke miljøfaktorer som kan være knyttet til disse opphopningene. Rothman har hevdet at man ikke skal utføre analyser basert på én enkelt observert klynge, han mener myndighetenes knappe ressurser bør settes inn når mer enn én opphopning er registrert på ulike tidspunkter og forskjellige steder (10). Thomas (11) og Elliott \& Wartenberg (9) har en mer pragmatisk holdning og mener at hvis et sett kriterier er oppfylt, kan man sette i gang en pasientkontroll-studie med målinger av eksponering overfor deltakerne i studien. Disse kriteriene er knyttet til resultatet av den statistiske analysen av opphopning, slik jeg har diskutert over, om tilsvarende funn er rapportert fra andre steder i verden, styrken på den anslåtte rateratio, antall tilfeller og om det finnes en plausibel biologisk mekanisme bak funnene.

\section{Konkusjon}

I Norge bør det være fagteam som kan undersøke bekymringsmeldinger, men helsemyndighetene bør på forhånd ha utarbeidet kriterier for når man skal initiere videre pasientkontroll-studier. Vi har gode helseregistre. Det er derfor en overkommelig oppgave å løfte en mistanke, basert på én observasjon, til et vitenskapelig forankret forskningsprosjekt, bruke gode helseregistre og produsere generaliserbare resultater.
Ved systematisk overvåking som en kontinuerlig prosess har vi sett at man både overser sanne klynger og genererer falske. En slik virksomhet kan derfor koste mer enn den smaker. Kunnskap om helseeffekter av ulike miljøeksponeringer basert på god epidemiologisk forskning er viktigere enn overvåking, fordi det er ut fra slike undersøkelser vi kan anslå kausale effekter.

\section{Geir Aamodt (f. 1962)}

er siv.ing. og har en doktorgrad i statistikk. Han er seniorforsker ved Folkehelseinstituttet og professor II ved Universitetet for miljø- og biovitenskap. Hans fagområder er statistiske metoder, geografisk fordeling av sykdom og miljøepidemiologi.

Ingen oppgitte interessekonflikter.

\section{Litteratur}

1. Committee on Medical Aspects of Radiation in the Environment (COMARE). Eleventh report the distribution of childhood leukaemia and other childhood cancers in Great Britain 1969-1993. Chilton, Didcot, Oxfordshire: Health Protection Agency, Radiation Protection Division, 2006.

2. Stiller CA, Kroll ME, Boyle PJ et al. Population mixing, socioeconomic status and incidence of childhood acute lymphoblastic leukaemia in England and Wales: analysis by census ward. Br J Cancer 2008; 98: 1006-11.

3. Vatn MH. Natural history and complications of IBD. Curr Gastroenterol Rep 2009; 11: 481-7.

4. Aamodt G, Bukholm G, Jahnsen J et al. The association between water supply and inflammatory bowel disease based on a 1990-1993 cohort study in southeastern Norway. Am J Epidemiol 2008; 168: 1065-72.

5. Bjerkedal T, Bakketeig LS. Surveillance of congenital malformations and other conditions of the newborn. Int J Epidemiol 1975; 4: $31-6$.

6. Lawson AB. Statistical methods in spatial epidemiology. Chichester: Wiley, 2001.

7. Cuzick J, Edwards R. Spatial clustering for inhomogeneous populations (with discussion). J R Statist Soc Series B 1990; B52: 73-104.

8. Aamodt G, Samuelsen SO, Skrondal A. A simulation study of three methods for detecting disease clusters. Int J Health Geogr 2006; 5: 15.

9. Elliott P, Wartenberg D. Spatial epidemiology: current approaches and future challenges. Environ Health Perspect 2004; 112: 998-1006.

10. Rothman KJ. A sobering start for the cluster busters' conference. Am J Epidemiol 1990; 132 (suppl 1): S6-13.

11. Thomas DC. Statistical methods in environmental epidemiology. Oxford: Oxford University Press, 2009

Mottatt 13.9. 2010, første revisjon innsendt 27.1.

2011, godkjent 3.3. 2011. Medisinsk redaktør Petter Gjersvik. 